\title{
長さの異なる貫通き裂の延性破壊進展評価*
}

\author{
須賀 一博*1, 菊池 正紀 ${ }^{* 2}$, 新井 洋平*1, 川崎 翔太*1
}

\section{Numerical Study for Ductile Fracture Process of Through Cracks of Different Lengths}

\author{
Kazuhiro SUGA*1, Masanori KIKUCHI, Yohei ARAI and Shota KAWASAKI \\ ${ }^{* 1}$ Department of Mechanical Engineering, Faculty of Science and Technology, Tokyo University of Science \\ 2641 Yamazaki, Noda, Chiba, 278-8510, Japan
}

The present study investigated ductile fracture process numerically by Gurson' s constitutive equation. Two parallel cracks having different length are located in the tensile specimen. The vertical and horizontal distances between two cracks are changed systematically. The load-displacement curves were simulated. The crack having larger length effects on the load-displacement curve at the initial stage of fracture. The significant decrease is observed in the load-displacement curve when the coalescence of cracks is occurred. The minimum value of the maximum load can be estimated by a simulation using a single crack whose length is same as the sum of two crack lengths. In addition, assessment method for multi-cracks problem was studied. The study found that $H / l$ criterion can estimate the maximum load reasonably, and also the consideration of the effect of $S$ in $H / l$ criterion may improve its estimation more reasonable.

Key Words : Ductile Fracture, Gurson Model, Numerical Simulation, Crack Propagation, Structural Assesment

\section{1. 緒言}

長い間構造物が運用されると, 応力腐食割れや熱疲労等によりき裂が発生する.き裂が発生した状況で, 地震 や事故などにより構造物に大きな負荷がかかると延性破壊が発生する可能性がある. 安全に運用するために，き 裂を有した構造物の健全性を評価することが重要である．一般にき裂が単独で存在することは少なく，複数のき 裂が同時に存在している.JSME およびASME の原子力維持規格 ${ }^{(1)}(2) に は$, 複数のき裂が存在する場合の延性破 壊評価法が示されている.

現在 , 長さの異なる複数のき裂が存在する場合の延性破壊評価方法には規格がない. 宮崎らは, 同一長さの $2 つ$ のき裂を有する平板の引張試験により得られた結果から, き裂間垂直距離 $H$ とき裂長さ $l$ の比 $H / l$ をパラメータ として, 最大荷重を予測する方法を提案している(3). 保守的かつ精度良い評価方法を提案するには,さまざま条件 で有効性を検証する必要がある．しかし，考慮すべき条件が多いため，実験による系統立った検証には多大な時 間と労力を要する.

本研究では，延性破壊シミュレーションを用いて，長さの異なる複数き裂の延性破壊挙動を検証する．筆者ら は, Gurson の構成式 ${ }^{(4)}$ を用いた複数き裂を有する平板試験片の延性破壊シミュレーションを行い, 弚の有効性を

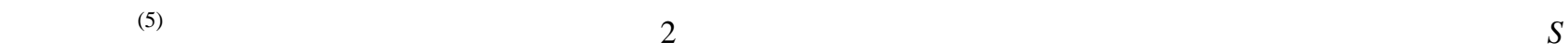
および垂直距離 $H$ を樣々に変化させ, き裂の進展挙動と最大荷重の推移を評価する . また, 宮崎らによって提案 された評価手法, ASME の原子力維持規格に示されている延性破壊評価方法の精度について検討する．

\footnotetext{
* 原稿受付 2011 年 6 月 3 日

${ }^{* 1}$ 東京理科大学機械工学科（广278-8510 千葉県野田市山崎 2641）

$*_{2}$ 正員, フェロー, 東京理科大学機械工学科

E-mail:ksuga@rs.noda.tus.ac.jp
} 


\section{2. シミュレーション手法}

延性破壞シミュレーションには，材料中のボイドの発生と成長を考慮した Gurson の構成式 ${ }^{(4)}$ 用いる.

$$
\Phi=\frac{3}{2} \frac{\sigma_{i j}^{\prime} \sigma_{i j}^{\prime}}{\bar{\sigma}_{m}^{2}}+2 q_{1} f^{*} \cosh \left(\frac{q_{2} \sigma_{k k}}{2 \bar{\sigma}_{m}}\right)-\left(1+q_{3} f^{* 2}\right)=0
$$

$f^{*}$ は修正ボイド率， $\sigma_{i j}^{\prime}$ は巨視的偏差応力， $\bar{\sigma}_{m}$ は母材の微視的相当応力を表す $. q_{1}, q_{2}, q_{3}$ は実験に合うよj に Tvergaardによって導入された修正パラメータであり， $q_{1}=1.5, q_{2}=1.0, q_{3}=q_{1}^{2}$ とした ${ }^{(6)}$.

修正ボイド率 $f^{*}$ は , ボイドの合体による応力積荷能力の低下をモデル化したもので, 次式で表現される .

$$
\begin{aligned}
& f^{*}= \begin{cases}f & \text { for } f \leq f_{c} \\
f_{c}+\frac{f_{u}^{*}-f_{c}}{f_{F}-f_{c}}\left(f-f_{c}\right) & \text { for } f>f_{c}\end{cases} \\
& f_{u}^{*}=\frac{1}{q_{1}}
\end{aligned}
$$

$f_{c}$ は臨界ボイド率であり，この值を境界として $f^{*}$ の増加が急激に高まり応力積荷能力が急激に減少する.$f_{F}$ は破 壞ボイド率であり，この值に達すると応力積荷能力が完全になくなるとする．

ボイドの変化量 $\dot{f}$ は, 式(4)で表される.

$$
\dot{f}=\dot{f}_{\text {growth }}+\dot{f}_{\text {nucleation }}
$$

$\dot{f}_{\text {growth }}$ は, ボイドの成長に関する項で, 式 (5) で与えられる.

$$
\dot{f}_{\text {growth }}=(1-f) \dot{\varepsilon}_{k k}^{p}
$$

$\dot{\varepsilon}_{k k}^{p}$ は, 塑性ひずみ増分である $\dot{f}_{n u c l e a t i o n}$ はボイドの発生に関する項で, 式 (6) で与えられる.

$$
\dot{f}_{\text {nucleation }}=A\left(\dot{\bar{\sigma}}_{m}+\frac{1}{3} \dot{\sigma}_{k k}\right)+B \dot{\bar{\varepsilon}}_{M}^{p}
$$

$\dot{\bar{\sigma}}_{m}$ は母材の相当応力増分， $\dot{\sigma}_{k k} / 3$ は静水圧増分， $\dot{\bar{\varepsilon}}_{m}^{p}$ は，母材の相当塑性ひずみ増分を表す . 右辺第一項は応力支

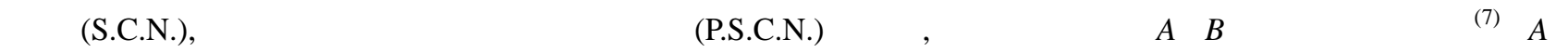
$B$ は材料特性值であり, 本研究では定数として扱う.

\section{3. 問 題 設 定}

長さの異なる貫通き裂の延性破壞挙動を検討するために，2つのき裂を有する平板引張試験の 3 次元

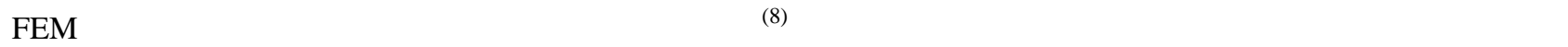

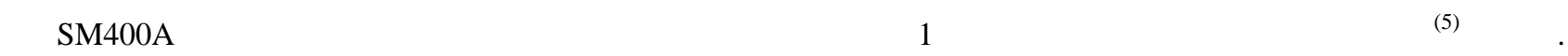

Table 1 Material constants

\begin{tabular}{l|r}
\hline Young's modulus [GPa] & 203 \\
\hline Poisson's ratio [-] & 0.3 \\
\hline Yield stress [MPa] & 304 \\
\hline Critical void volume fraction [-] & 0.113 \\
\hline Void volume fraction at fracture [-] & 0.188 \\
\hline S.C.N. & $1.5 \times 10^{-6}$ \\
\hline P.S.C.N & $2.5 \times 10^{-2}$ \\
\hline Coefficient of the hardening rule & $5.81 \times 10^{2}$ \\
\hline Exponent of the hardening rule & 0.533 \\
\hline
\end{tabular}


試験片寸法を図 1 に示す . 初期き裂寸法は， $l_{\text {max }}=20 \mathrm{~mm}$ と $l_{\min }=10 \mathrm{~mm}$ とした . また , $S=10 \mathrm{~mm}, H=10 \mathrm{~mm}$ としたときの，き裂近傍の FEM モデルを図 2 に示す．Gurson の構成式を用いたシミュレーション結果は要素サイ ズに依存することが知られているため，本研究で用いる FEM モデルでは，き裂前縁部の要素サイズを $1.0 \mathrm{~mm} \times$ $0.5 \mathrm{~mm} \times 0.5 \mathrm{~mm}$ とした .

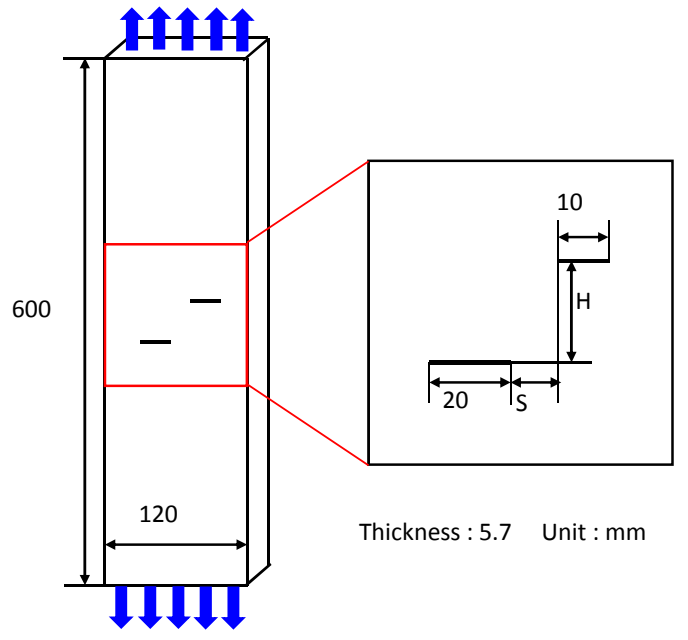

Fig. 1 Specimen with two cracks

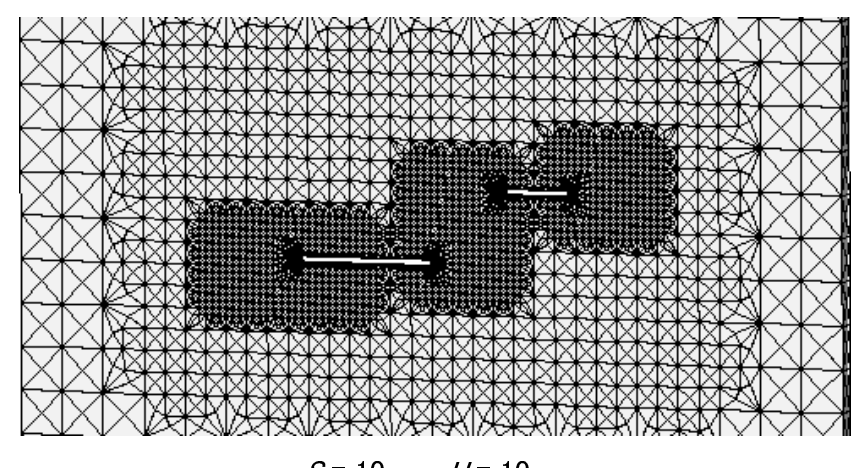

$S=10 \mathrm{~mm} \quad H=10 \mathrm{~mm}$

Num. of nodes: 22558

Num. of elements: 90672

Fig. 2 FEM model

き裂間水平距離 $S$ および垂直間距離 $H$ を変更し，き裂を配置した．組合せは，表 2 に示す 31 通りとした .

Table 2 Combinations of $S$ and $H$

\begin{tabular}{c|r|r||r|r|r}
\hline Case & $S[\mathrm{~mm}]$ & $H[\mathrm{~mm}]$ & Case & $S[\mathrm{~mm}]$ & $H[\mathrm{~mm}]$ \\
\hline 1 & -4 & 5 & 17 & 5 & 15 \\
\hline 2 & -4 & 10 & 18 & 5 & 20 \\
\hline 3 & -4 & 20 & 19 & 5 & 30 \\
\hline 4 & -4 & 30 & 20 & 10 & 0 \\
\hline 5 & -2 & 5 & 21 & 10 & 5 \\
\hline 6 & -2 & 10 & 22 & 10 & 10 \\
\hline 7 & -2 & 15 & 23 & 10 & 15 \\
\hline 8 & -2 & 20 & 24 & 10 & 20 \\
\hline 9 & -2 & 30 & 25 & 10 & 30 \\
\hline 10 & 0 & 5 & 26 & 15 & 0 \\
\hline 11 & 0 & 10 & 27 & 15 & 5 \\
\hline 12 & 0 & 15 & 28 & 15 & 10 \\
\hline 13 & 0 & 30 & 29 & 15 & 15 \\
\hline 14 & 5 & 0 & 30 & 15 & 20 \\
\hline 15 & 5 & 5 & 31 & 15 & 30 \\
\hline 16 & 5 & 10 & & & \\
\hline & & & & & \\
\hline
\end{tabular}

\section{4. シミュレーション結果}

$S=-2 \mathrm{~mm}, 0 \mathrm{~mm}, 10 \mathrm{~mm}, 15 \mathrm{~mm}$ の場合について, 荷重変位曲線と延性破壊の樣子を示す.試験片への負荷 レベルを試験片上端における変位 $\delta$ で表す $. S=-4 \mathrm{~mm}$ は $S=-2 \mathrm{~mm}$ と， $S=5 \mathrm{~mm}$ は $S=10 \mathrm{~mm}$ とほぼ同樣の 傾向を示した . 


\section{1 $S=-2$ mm の場合}

き裂間水平方向距離 $S=-2 \mathrm{~mm}$ と固定して,$H$ を変化させた場合の荷重変位線を図 3 に示す. Single Crack(Length $=28 \mathrm{~mm})$ は, き裂長さの合計 $30 \mathrm{~mm}$ から , き裂の重なる長さ $2 \mathrm{~mm}$ を除いた $28 \mathrm{~mm}$ の単独き裂が存在すると仮 定して, シミュレーションを行った結果である. Single Crack(Length $=20 \mathrm{~mm})$ は, 大きい方のき裂が単独で存在 すると仮定してシミュレーションを行った結果である .

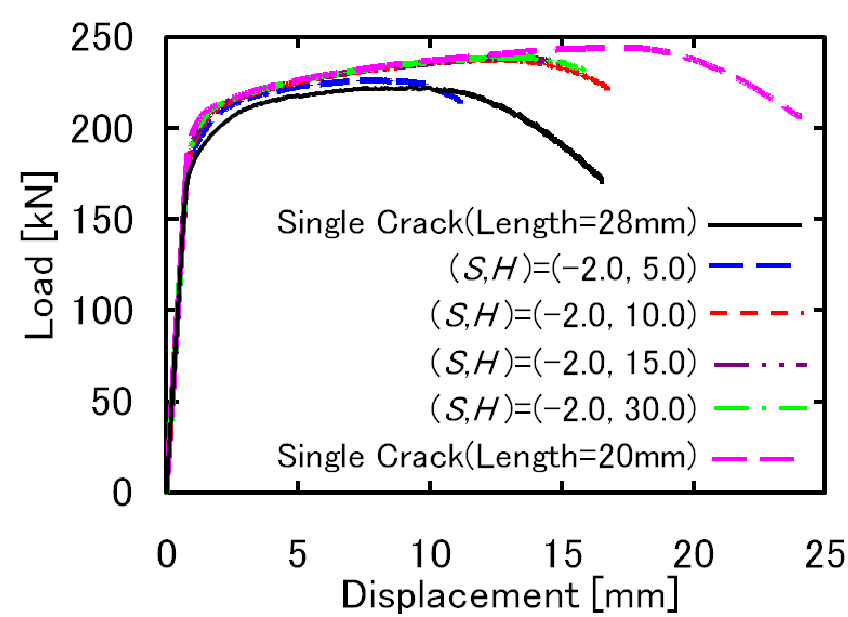

Fig. 3 Load-displacement curve $(S=-2 \mathrm{~mm})$

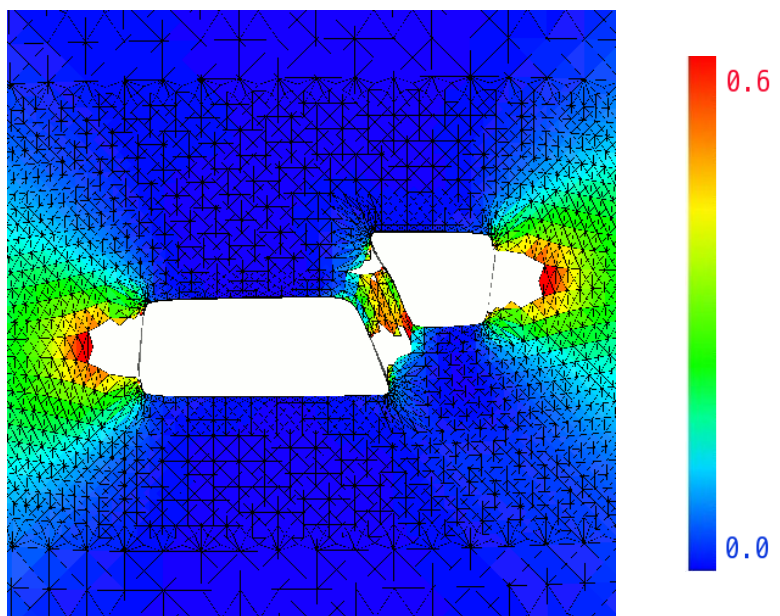

Fig. 4 Fracture pattern $(S=-2 \mathrm{~mm}, H=5 \mathrm{~mm}, \delta=11 \mathrm{~mm})$

$S=-2 \mathrm{~mm}, H=5 \mathrm{~mm}$ の場合のみ，き裂の合体が起こった . 合体が起こった直後に荷重が減少した .き裂が合 体する直前の破壞の樣子を図 4 に示す. カラー分布は , 相当塑性ひずみの大きさを示している .

兴の他の $H$ においては, 合体は起こらなかった . 合体が起こらない場合の荷重変位曲線は, Single Crack(Length $=20 \mathrm{~mm})$ のものと良く似た挙動を示した .

$4.2 S=0 \mathbf{~ m m}$ の場合

き裂間水平方向距離 $S=0 \mathrm{~mm}$ と固定して,$H$ を変化させた場合の荷重変位曲線を図 5 に示す. Single Crack(Length $=30 \mathrm{~mm}$ ) は, 2 つの初期き裂長さの合計 $30 \mathrm{~mm}$ の大きさの単独き裂が存在すると仮定して , シミュレーションを 行った結果である .

$H=5.0 \mathrm{~mm}$ の場合は, き裂の合体が起こった . 変形初期において , 荷重変位曲線は Single Crack $($ Length $=20$ $\mathrm{mm})$ の結果と良く似た傾向を示した．合体後は，荷重が大きく低下し， Single Crack(Length = 30 mm)のものと同 樣の傾向を示した.

$H=10 \mathrm{~mm}, 15 \mathrm{~mm}$ の場合は，き裂同士が合体しなかったが，荷重の低下は起こった．破壊形式を図 6,7 に示 す．いずれの場合も相当塑性ひずみ領域の高い領域へ向かってき裂が進展する樣子か確認できた $. H=10 \mathrm{~mm}$ の 場合には, 大きい方のき裂の右端部と小さい方のき裂の左端部を結ぶ領域に相当塑性ひずみの高い領域が発生し た . $H=15 \mathrm{~mm}$ の場合には, 大きい方のき裂両端において, 初期き裂と平行な方向に相当塑性ひずみの高い領域 が発生した .さらに，大きい方のき裂が初期き裂と平行な方向へ進展した後，大きい方のき裂の右端部と小さい 方のき裂の右端部を結ぶ領域に相当塑性ひずみの高い領域が発生した $H=30 \mathrm{~mm}$ の場合は, き裂の合体が起こ らなかった . 荷重変位曲線は, Single Crack $($ Length $=20 \mathrm{~mm})$ の結果と常に一致する傾向を示した .この場合 , 10 mmのき裂はほとんど進展しなかった .

\section{$4.3 S=10 \mathrm{~mm}$ の場合}

き裂間水平方向距離 $S=10 \mathrm{~mm}$ と固定して,$H$ を変化させた場合の荷重変位曲線を図 8 に示す.

$H=0 \mathrm{~mm}, 10 \mathrm{~mm}$ の場合は, き裂の合体が起こった．いずれの場合にも，荷重変位曲線は合体以前は Single

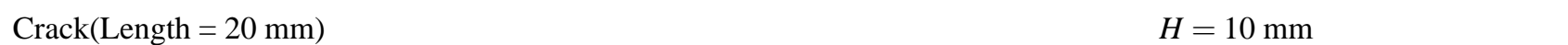
の破壊形式を図 9 に示す. 


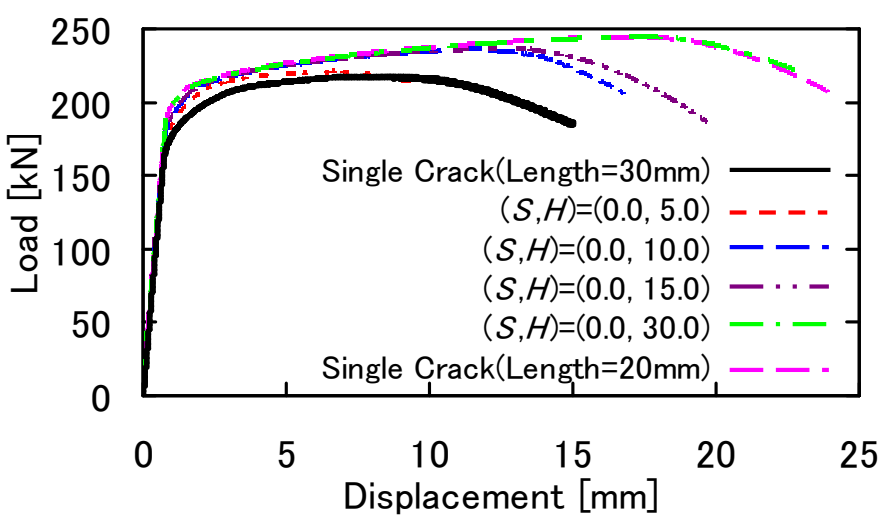

Fig. 5 Load-displacement curve $(S=0 \mathrm{~mm})$

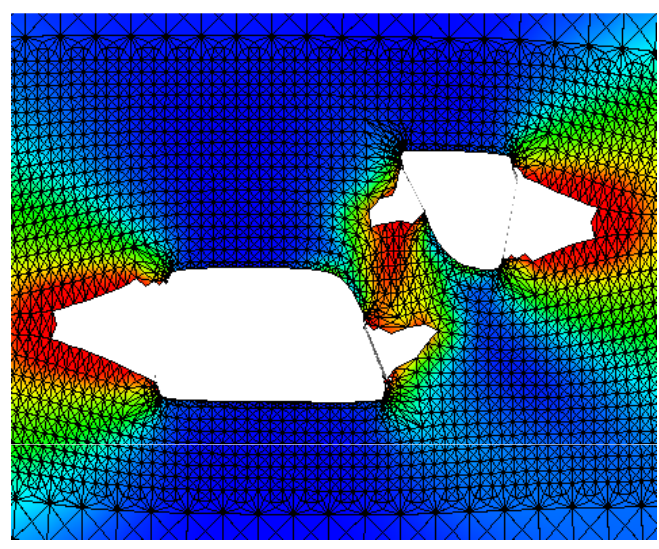

Fig. 6 Fracture pattern

$(S=0 \mathrm{~mm}, H=10 \mathrm{~mm}, \delta=16 \mathrm{~mm})$

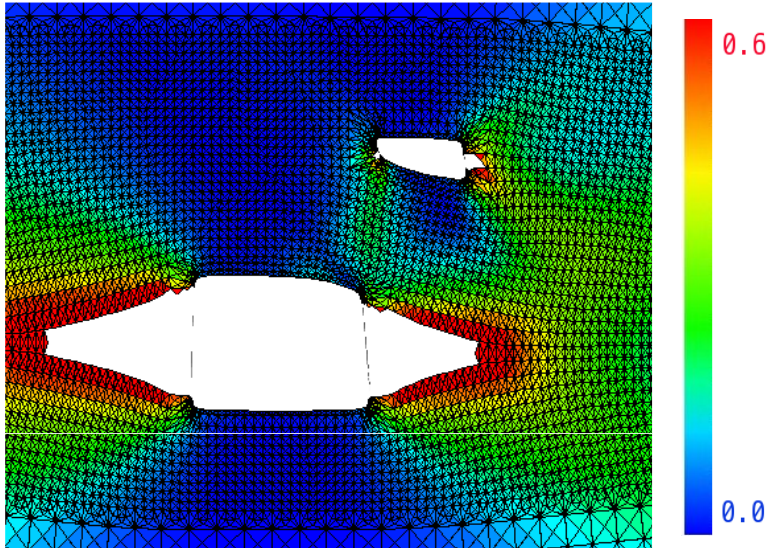

Fig. 7 Fracture pattern $(S=0 \mathrm{~mm}, H=15 \mathrm{~mm}, \delta=20 \mathrm{~mm})$

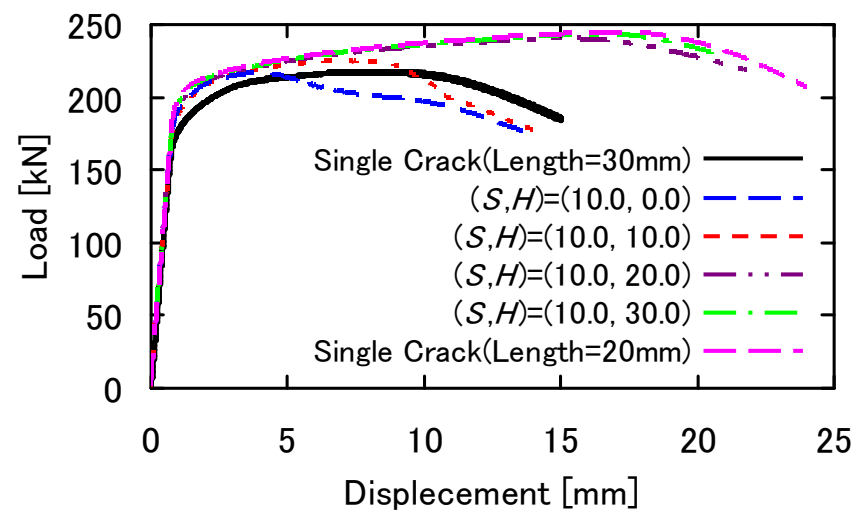

Fig. 8 Load-displacement curve $(S=10 \mathrm{~mm})$

$H=20 \mathrm{~mm}, 30 \mathrm{~mm}$ の場合は，き裂の合体が起こらなかった . 荷重変位曲線は , 常に Single Crack $(\operatorname{Length}=20$ $\mathrm{mm})$ のものと同じ挙動を示した $. H=20 \mathrm{~mm}$ とした場合の, 破壊の樣子を図 10 に示す. $H=10 \mathrm{~mm}$ の合体した 場合に比べ(図 9)，H=20 mm では，負荷レベル $\delta$ が大きくなっても，き裂間を結ゔ領域における相当塑性ひず みの值が小さいことが分かる . 

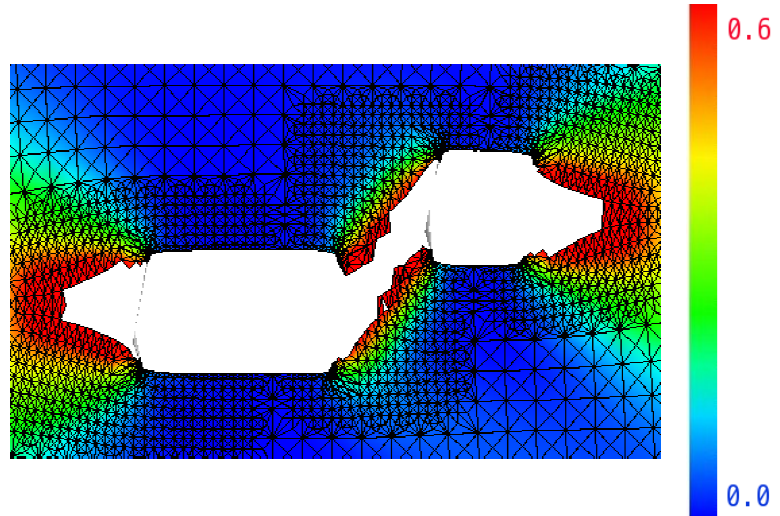

Fig. 9 Fracture pattern

$(S=10 \mathrm{~mm}, H=10 \mathrm{~mm}, \delta=14 \mathrm{~mm})$

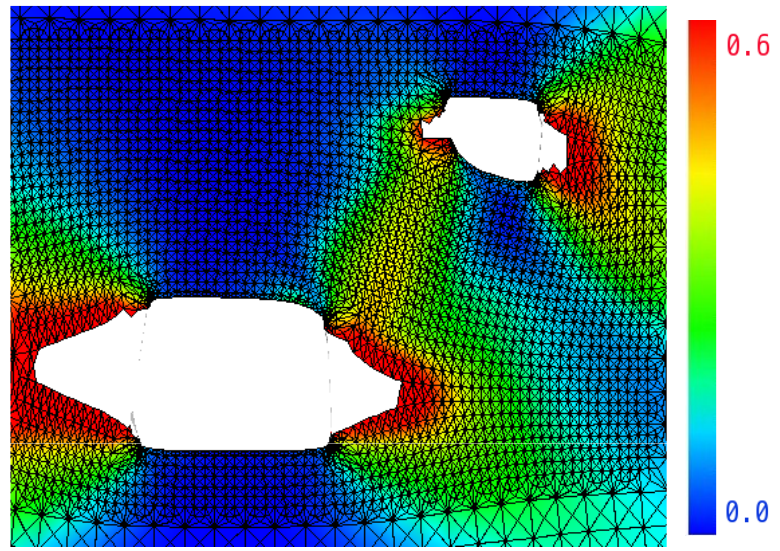

Fig. 10 Fracture pattern

$(S=10 \mathrm{~mm}, H=20 \mathrm{~mm}, \delta=22 \mathrm{~mm})$

$4.4 S=15 \mathrm{~mm}$ の場合

き裂間水平方向距離 $S=15 \mathrm{~mm}$ と固定して， $H$ を変化させた場合の荷重変位曲線を図 11 に示す。
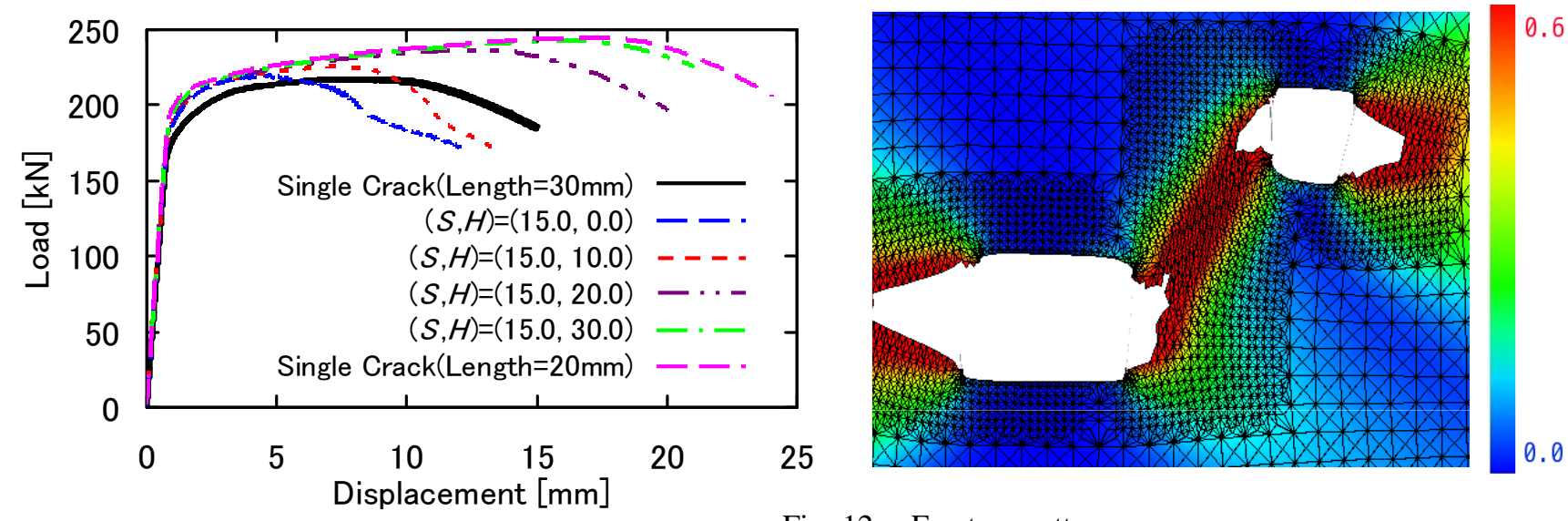

Fig. 12 Fracture pattern

Fig. 11 Load-displacement curve $(S=15 \mathrm{~mm})$

$(S=15 \mathrm{~mm}, H=20 \mathrm{~mm}, \delta=19 \mathrm{~mm})$

$H=0 \mathrm{~mm}, 10 \mathrm{~mm}$ の場合は, き裂の合体が起こった．いずれの場合にも，荷重変位曲線は合体以前は Single Crack $($ Length $=20 \mathrm{~mm})$ のものと似た挙動を示し，合体後は荷重が大きく低下した .

$H=20 \mathrm{~mm}, 30 \mathrm{~mm}$ の場合は, き裂の合体が起こらなかった . $H=30 \mathrm{~mm}$ の場合には, 荷重変位曲線が Single Crack $($ Length $=20 \mathrm{~mm})$ のものと同じ挙動を示した . しかし,$H=20 \mathrm{~mm}$ の場合は，途中で荷重の低下が起こった . $H=20 \mathrm{~mm}$ とした場合での， $\delta=19 \mathrm{~mm}$ における破壤の樣子を図 12 に示す.き裂間を結引䕘域で相当塑性ひずみ の值が大きくなっていることが分かる . また , $(S=10 \mathrm{~mm}, H=20 \mathrm{~mm})$ では, $\delta=20 \mathrm{~mm}$ を過ぎても荷重変位曲 線が Single Crack(Length $=20 \mathrm{~mm})$ とほぼ同樣の傾向を示した (図 8). 一方， $(S=15 \mathrm{~mm}, H=20 \mathrm{~mm}$ ) の場合では， $\delta=20 \mathrm{~mm}$ において，2 割程度の荷重の低下 (約 50kN) が観測された (図 11). 図 10，12 を比較すると，荷重低下 の起こった $(S=15 \mathrm{~mm}, H=20 \mathrm{~mm})$ の場合では, き裂を結ふ䕘域において相当塑性ひずみが高い值を示してい ることが分かる．き裂間相互作用の結果, 相当塑性ひずみが高くなったと考えられるが, 詳細なメカニズムの検 討は , 今後の課題としたい .

以上のシミュレーション結果から，荷重変位曲線の推移について以下の傾向があることが分かる．延性破壊の 
初期段階では， $l_{\max }$ のき裂の挙動が，荷重変位曲線に支配的な影響を与えている．さらに破壊が進展し，2つのき 裂が合体すると大きな荷重低下が起こる．最大荷重值の下限值は， $l_{\max }+l_{\min }$ の長さの単独き裂が存在する場合の 結果から見積もることが可能である . 合体に至らない場合でも，き裂間相互作用が大きいほど荷重の低下度合も 大きい傾向がある . 相互作用の大きさは，き裂間を結ふ䕘域の相当塑性ひずみの大きさに依存する可能性がある .

\section{5. 評 価 法 の 検 討}

構造物の健全性評価のためには, き裂を有する構造物の積載できる最大荷重を適切に評価することが重要であ る . 宮崎らは, 同じ長さの貫通き裂を 2 つ有する平板の引張試験を行い, 垂直距離 $H$ とき裂長さ $l$ から, 最大荷 重値 $P_{\text {est }}$ を予測する $H / l$ クライテリオンを提案した ${ }^{(8)}$.

$$
\begin{array}{ll}
P_{\text {est }}=F_{c}+\left(F_{s}-F_{c}\right) \times \frac{H}{l} & \text { for } \frac{H}{l} \leq 1 \\
P_{\text {est }}=F_{s} & \text { for } \frac{H}{l}>1
\end{array}
$$

$F_{c}$ は 2 つき裂が同一平面に存在するとして評価した最大荷重， $F_{s}$ は長さ $l$ のき裂が単独で存在するとして評価し た最大荷重を表す.

$H=0$ (同一平面) として $S$ を变化させ行ったシミュレーションにより得られた荷重変位曲線から， $F_{c}$ を決定した. また，単独き裂が存在するとして行ったシミュレーションにより得られた荷重変位曲線から， $F_{s}$ を決定した . 決 定した $F_{c}, F_{s}$ から $H / l$ クライテリオンを用いて予測した最大荷重と, $S$ および $H$ を樣々に変化させ行ったき裂の 進展シミュレーションから得られた最大荷重を比較した。

$H / l$ クライテリオンでは, 2 つのき裂長さは $l$ で同一と仮定されている . 本研究では, 異なる長さのき裂の破壊 過程を対象としている.したがって,$l$ として長い方のき裂長さ $l=l_{\text {max }}$ を採用する場合と, 短い方のき裂 $l=l_{\text {min }}$ を採用する場合の 2 通り考えられる．どちらを採用するか決定するために， $S=10 \mathrm{~mm}$ として,$H / l$ クライテリ オンによる最大荷重の評価を行った . 結果を図 13 に示す．

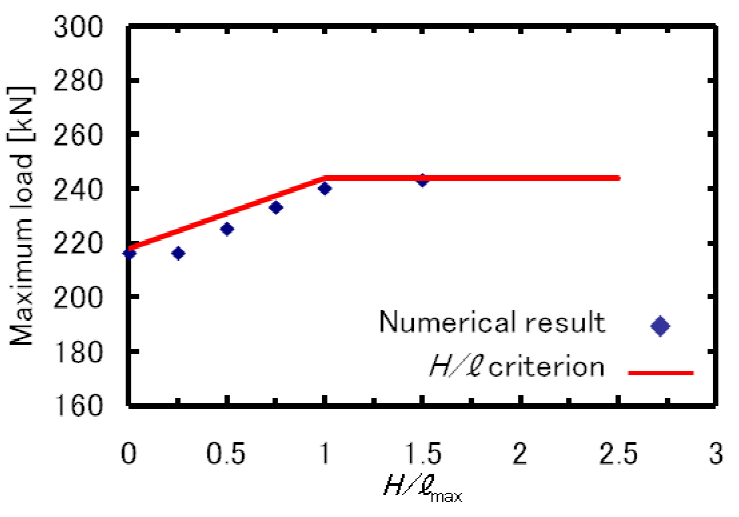

(a) $l=l_{\max }$

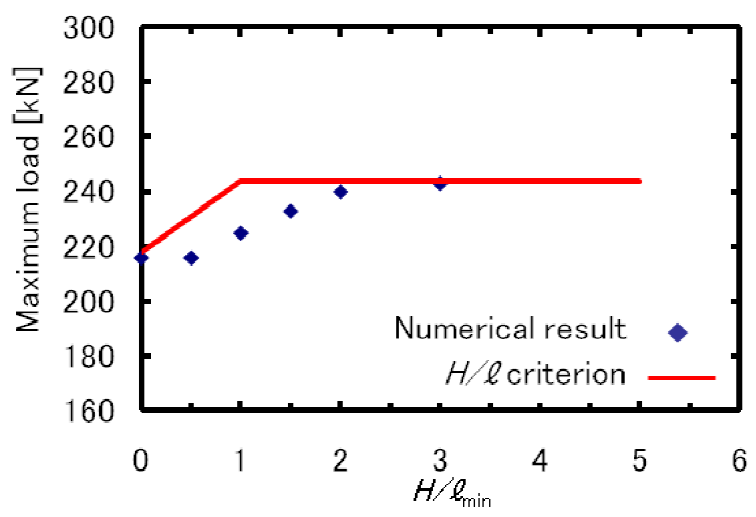

(b) $l=l_{\min }$

Fig. 13 Estimation of maximum load by $l_{\max }$ and $l_{\text {min }}$

图 13 より，l= $l_{\max }$ として評価した方がよりシミュレーション結果に近い評価となることが分かる．さらに， $H / l_{\max }>1$ の場合には, $l=l_{\max }$ のき裂が単独で存在すると仮定して最大荷重を評価することができる . この事実 は, $l=l_{\max }$ のき裂が他のき裂に及ぼす影響の範囲が, 上下方向に $l_{\max }$ 程度あることを示唆しているのではないか と考えられる．したがって，以下では， $l=l_{\max }$ として評価を行った . 結果を図 14 に示す．

$H / l_{\max }$ が 0 から 1 付近に向かって最大荷重が上昇し、弚の後一定值となる傾向が両者で良く一致している.ま

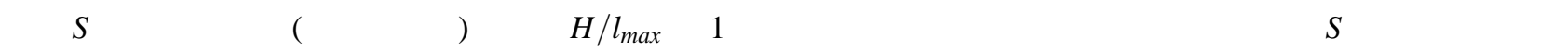
つれ，最大荷重が一定となる $H / l_{\max }$ の値も大きくなる傾向を示した.$S$ が大きい場合 $(S=15 \mathrm{~mm})$ には，最大荷 


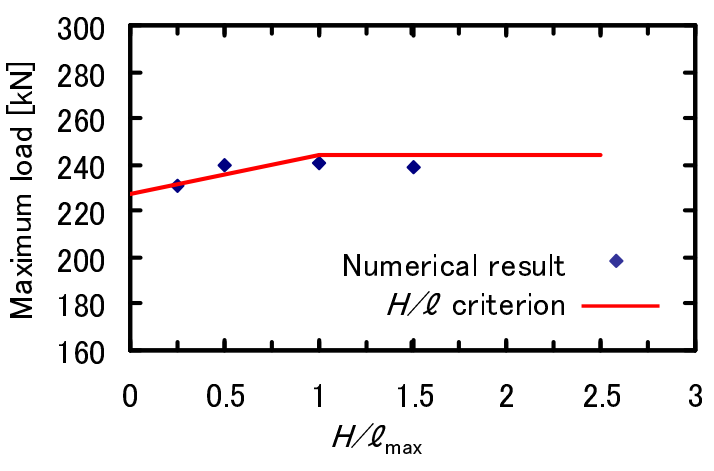

(a) $S=-4$

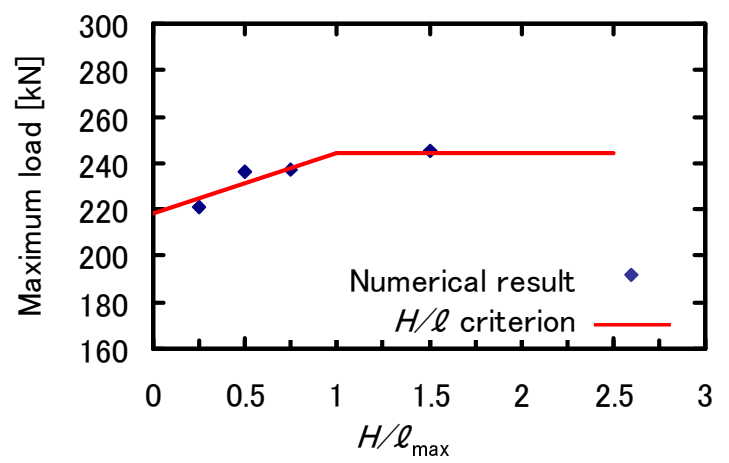

(c) $S=0$

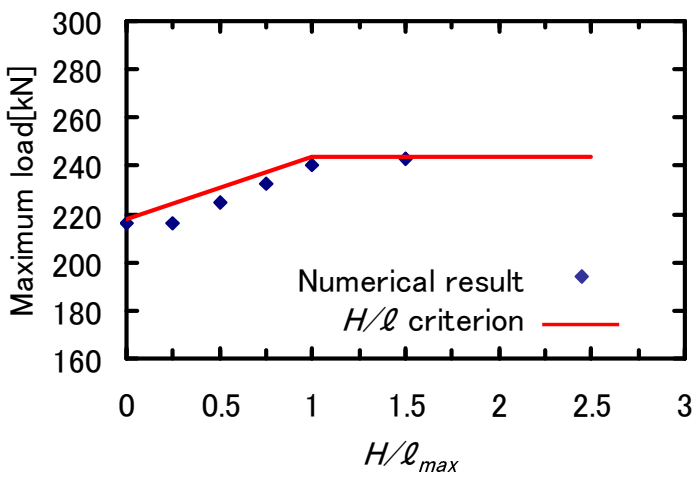

(e) $S=10$

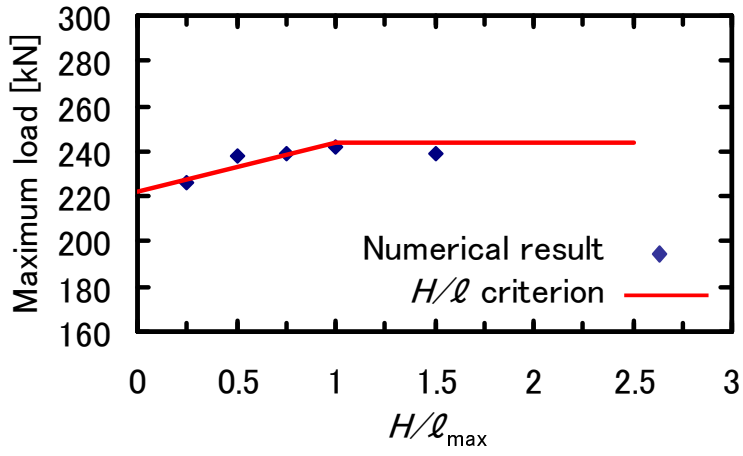

(b) $S=-2$

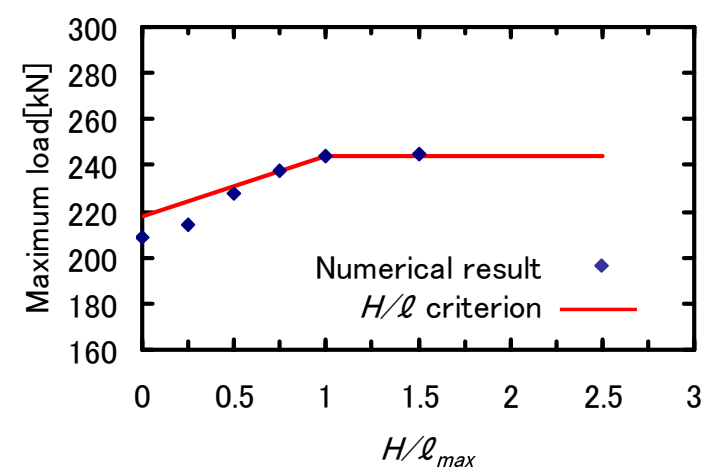

(d) $S=5$

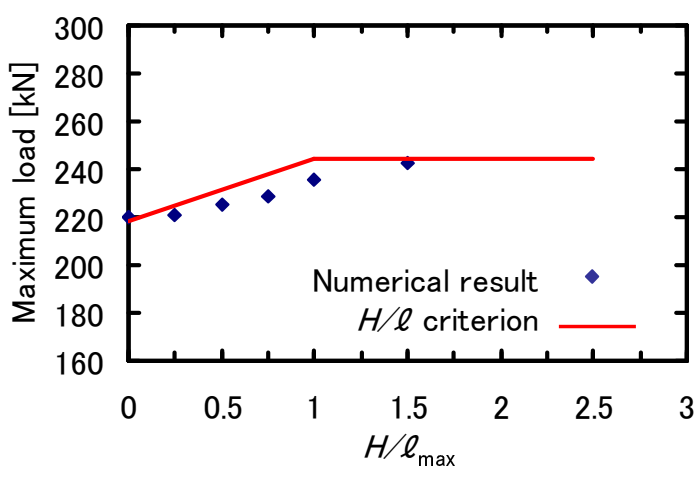

(f) $S=15$

Fig. 14 Comparison of maximum load between $H / l$ criterion and numerical simulation

重を高めに評価する傾向がみられる．すなわち，非保守的な評価となる． $H / l_{\max }$ に加え， $S$ に関する条件を考慮 することで，より高い精度での最大荷重予測が期待できる．

ASME Sectioin XI ${ }^{(2)}$ では，以下のように最大荷重を評価する .

$$
\begin{gathered}
P_{\text {est }}=F_{c} \quad(H \leq 12.5 \mathrm{~mm}) \\
P_{\text {est }}=F_{s} \quad(H>12.5 \mathrm{~mm})
\end{gathered}
$$

$H / l_{\max }$ クライテリオンおよび Section XI により評価した最大荷重を，数值シミュレーションにより得られた最 大荷重と比較した . 結果を図 15 に示す.縦軸には，シミュレーションにより得られた最大荷重を示している.破 
線に近いほど，精度の高い予測が行われたことを示している.Section XI により予測された最大荷重は，230 kN を境界として、小さい荷重では大きめに、大きい荷重では小さめに最大荷重を予測することが分かる $. H / l_{\max }$ ク ライテリオンに予測された最大荷重は, シミュレーション結果より大きく評価される傾向がある．しかし，破線 に近い值を予測している．图 16 の網掛けの領域は, 破線からの誤差が $\pm 5 \%$ の範囲を示している $. H / l_{\max }$ クライ テリオンは，予測誤差 $\pm 5 \%$ 程度で最大荷重を予測した 。一方，ASME Section XI は，予測誤差 $\pm 10 \%$ 程度で最大 荷重を予測した。

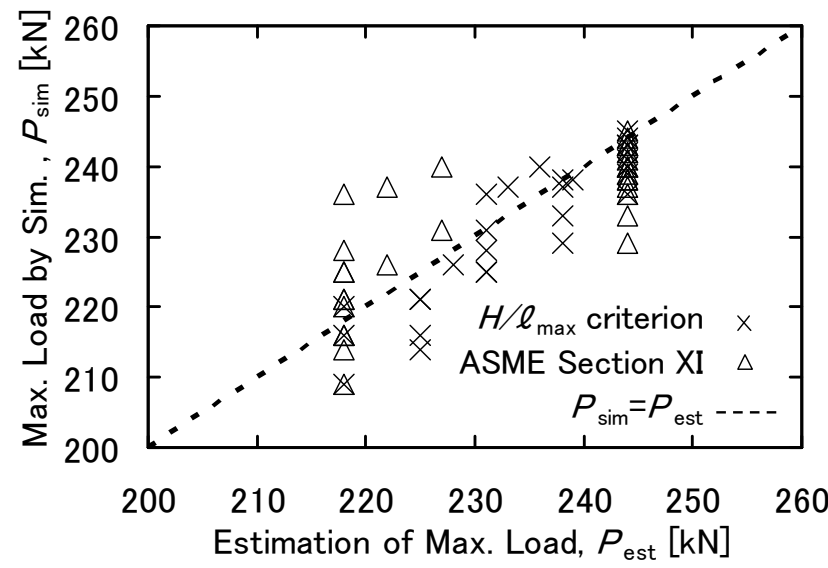

Fig. 15 Estimation of $P_{\max }$

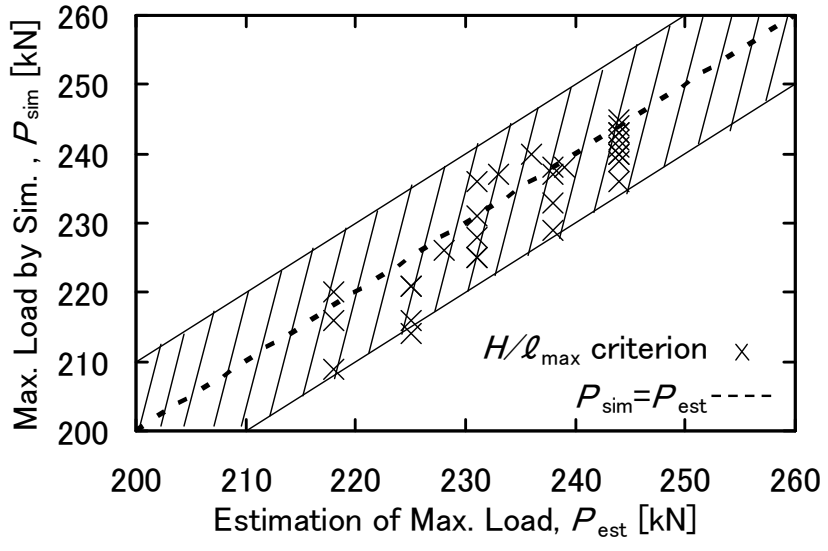

Fig. 16 Error range of estimation by $H / l_{\max }$ criterion

\section{6. 結言}

長さの異なる複数き裂の延性破壊挙動を数值シミュレーションを用いて検証した . 水平方向距離 $S$ と垂直方向 距離 $H$ を変化させた場合の最大荷重の変化を観察し，以下の結論を得た .

・延性破壞の初期段階では，長いき裂の挙動が荷重変位曲線に支配的な影響を与える．

・破壊が進展し，2つのき裂が合体し大きな荷重低下が起こる．

・き裂が合体しない場合でも，き裂を結ぶ領域に大きな相当塑性ひずみが発生すると荷重低下が起こる．

- 2 つのき裂長さの合計と同じ長さの単独き裂のシミュレーション結果から，最大荷重の下限値を見積もれる． 複数き裂の延性破壊評価手法について検討し，以下の結論を得た .

・ $H / l_{\max }$ クライテリオンを用いることで, 精度の高い延性破壊評価ができる.

-き裂間水平方向距離 $S$ を考慮することで $H / l_{\max }$ クライテリオンの予測精度を向上できる可能性がある.$S$ の 影響を考慮した評価手法の提案は, 今後の課題としたい .

$$
\text { 文献 }
$$

（1）日本機械学会，発電用原子力設備規格，維持規格 (2004 年版), JSME S NA 1-24, (2004).

(2) The Americal Society of Mechanical Engineers, 2007, "2007 ASME Boiler and Pressure Vessel Code Section XI Rules for Inservice Inspection of Nuclear Power Plant Components".

(3) K. Miyazaki, K. Hasegawa, K. Saito, ”Discussion of Flas Alignment Rule for Fully Ductile Fracture (Effect of Multiple Flaws with Different Length)", Working Group on Pipe Flaw Evaluation in ASME Code Section XI Meeting, (2010).

(4) Gurson, A.L., "Continuum Theory of Ductile Rupture by Void Nucleation and Growth: Part I Yield Criteria and Flow Rules for Porous Ductile Media", Transaction of the ASME, Jounal of Engineering Materials and Technology, Vol. 99 (1977), pp. 2-15.

(5) 須賀一博, 川崎翔太, 菊池正紀, ”複数き裂の延性破壊シミュレーション”, 日本機械学会論文集 A 編, Vol. 77, No. 777, (2011), pp.803-812.

(6) Tvergaard, V., "3D-analysis of Localization Failure in a Ductile Material Containing Two Size-scales of Spherical Particles", Engineering Fracture Mechanics, 31 (1988), pp. 421-436. 
(7) C.C.Chu, A.Needleman, "Void nucleation effects in biaxially stretched sheets", Journal of Engineering Materials and Technology, Vol. 102 (1980), pp. 249-256.

(8) K. Miyazaki, K. Saito, K. Hasegawa, and B. Bezensek, "Experimental study of ductile fracture for non-aligned multiple flaws in a plate", ASME Pressure Vessels and Piping Division Conference, PVP2009-77103 (2009). 